\title{
Dry Matter Accumulation in Sunflower and Maize Leaves as Measured by an Improved Half-Leaf Method*
}

\author{
by Nobuo Nomoto,** and Toshiro SAEKI***
}

\author{
Received July 15,1968
}

\begin{abstract}
An improvement of the half-leaf method was made by the application of steaming to conducting cells to stop translocative outflow of assimilates. The improved method was used for obtaining the diurnal change of the photosynthetic accumulation, translocative outflow and respiratory loss of matter in fully exposed leaves of sunflower and maize plants. The maximum rates of photosynthesis obtained, $28 \mathrm{mg}$ dry matter $/ \mathrm{dm}^{2} / \mathrm{hr}$ for sunflower and $40 \mathrm{mg}$ for maize were comparable to those reported recently by the improved gasometric leaf-chamber methods. The photosynthetic activity proceeded roughly in parallel with the change of light intensity, and the variation of photosynthetic $\mathrm{CO}_{2}$-fixation was closely followed by that of translocation; hence most of the translocative outflow of assimilates occurred in daylight hours.
\end{abstract}

\section{Introduction}

Since the first employment of the half-leaf method by Sachs ${ }^{1)}$ for measuring $\mathrm{CO}_{z}$ fixation in leaves, this method has been subjected to detailed inspection and improvement ${ }^{2,3,4)}$. The methods was, however, gradually superseded by the gasometric method which involved enclosing leaves in a leaf chamber. The latter has contributed to a vast amount of our knowledge with regard to the physiological characteristics of photosynthesis and respiration, but its accuracy has rather blindly been believed. Recently, an increasing incredulity has been aroused to the gasometric leaf-chamber method. Criticisms were focussed on the excess elevation of leaf temperature and the $\mathrm{CO}_{2}$ depression very near the leaf surface ${ }^{5,6,7)}$. Although a substantial improvement of the leaf-chamber method might be possible, a rigid adherence to it in all facets of photosynthesis measurement will be wrong.

On the other hand, the half-leaf method possesses many characteristic merits; it does not alter artificially the natural micro-environment; it does not necessitate costly equipments; it gives us directly dry-matter increment instead of $\mathrm{CO}_{2}$ absorption; it easily produces an average value of photosynthetic rates of several leaves, a task very troublesome and time-consuming in the leaf-chamber method.

The present paper describes an improvement of the half-leaf method by an application of steaming of petioles to stop translocation stream. The new technique was applied to obtaining the diurnal change of the accumulation and translocation of matter in sunflower and maize leaves.

* Partially supported by Special Project Research, "Studies on the Dynamic Status of Biosphere" granted by the Ministry of Education, and carried out as a part of JIBP/PP.

** Department of Biology, Faculty of Science, Ibraraki University, Mito.

*** Department of Botany, Faculty of Science, University of Tokyo, Hongo, Tokyo. 


\section{Method}

The rate of photosynthesis was calculated as the average of dry-weight increments per unit area of six or eight similar leaves. The experimental leaves were selected from young matured leaves at exposed positions. In order to facilitate the detection of the selected leaves they were each tagged with a small piece of red vinyl tape bearing the number to show the experimental order. The petioles of the sunflower leaves were steamed by a modified aspirator for about one minute to prevent translocation of photosynthates from the lamina (Photo. 1). In the case of maize leaf, a one-minute steaming was applied across the midrib to the part $5 \mathrm{~cm}$ above the basal end of the lamina. After the steaming a large piece was cut out from the left or right half of each lamina. At the beginning of the cuttings the correct time was recorded. These six or eight leaf pieces constituted the control pieces.

Under a shelter the control pieces were arranged without overlap on a sheet of photographic printing paper and covered with a transparent glass or plastic plate. The images of the leaf pieces were clearly marked on the paper in a few seconds under the sun, or in a few minutes even under a cloudy weather. The prints were enclosed in a light-proof envelope for later planimetering. The leaf pieces were then exposed to the steam of boiling water to kill the leaf tissues. Each of the leaf pieces was then wrapped in a thin paper marked with the number of experimental order.

Usually about two hours later the experimental pieces were cut out from the remaining half-leaves, and followed by the same procedure as in the control pieces. The steamed petioles or veins were found liable to bending, which was feared to obstruct the free conduction of transpiration stream and alter the radiation environment of the leaves. After some trials we found that the bending can easily be avoided by wrapping the steamed petioles with one or two sheets of alminium foil.

After a successive series of measurement in one day, all the samples were brought to the laboratory and dried in a forced-air oven at $80^{\circ}$. The samples were then cooled in a desiccator in the balance room. The dry weights were determined to $0.1 \mathrm{mg}$. The weight determinations were made rapidly with a Mettler balance of Macro Digital $\mathrm{H}$ type.

The rate of photosynthesis in dry matter $(q)$ was calculated according to the following equation :

$$
\begin{gathered}
q=\frac{1}{n} \sum^{n} \frac{W_{2} / A_{2}-W_{1} / A_{1}}{t_{2}-t_{1}} \mathrm{mg} . \\
\mathrm{dm}^{-2} \cdot \mathrm{hr}^{-1} \ldots \ldots \ldots \ldots
\end{gathered}
$$

Here, $A_{1}$ and $W_{1}$ indicate respectively the area and dry weight of each control piece, at the first sampling time $t_{1}$; $A_{2}$ and $W_{2}$, of each experimental piece at the second sampling time $t_{2} ; n$, the number of sample leaves.

The main improvement of the present method lies in the killing of conducting cells by steaming. Since the midribs of maize leaves are me-

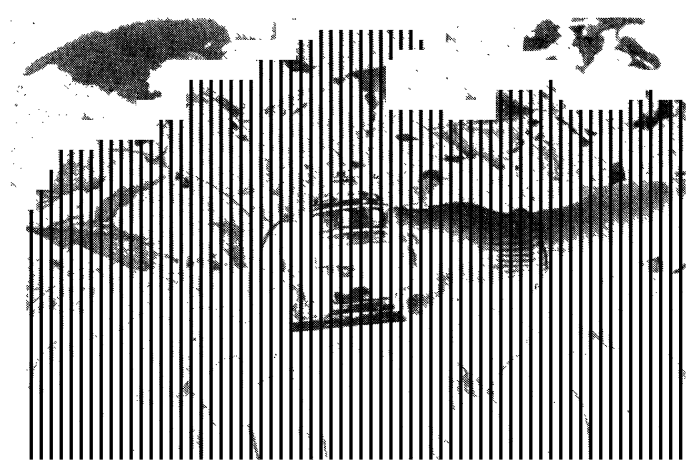

Photo. 1. 
chanically tough, we examined if the one-minute steaming is sufficient for preventing translocation. Table 1 indicates that there was no significant decrease in the rate of dry matter accumulation, even when the duration of steaming was abbreviated to 30 seconds, in contrast to a significant decrease of accumulation in the control blades without steaming.

The amount of translocation was calculated as the difference of dry-matter change per unit area between the leaves with and without steaming of petioles. The rate of respiratory loss of dry matter was determined as follows. Before the dusk the control pieces were taken as usual. The remaining half-leaves was wrapped loosely with an aluminium foil to prevent light invation but not to interfere free diffusion
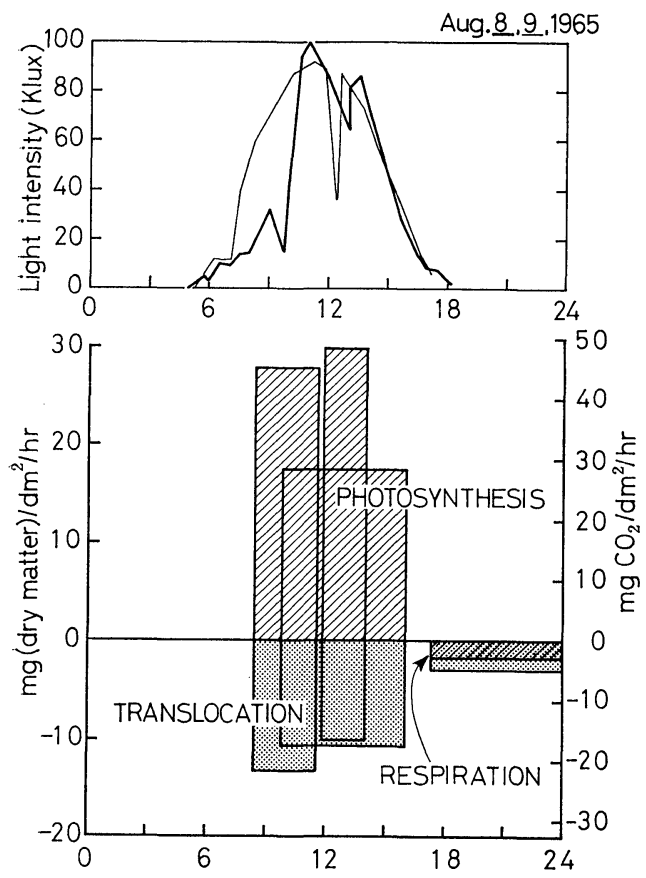

Fig. 1. Diurnal variations in the rate of photosynthesis and translocation, together with night respiration, in maize leaves (bottom), and solar light intensity (top). Measured on August 8 and 9, 1965. of gases to and from the leaves. The experimental pieces were sampled after sunrise, while the sunlight is not intense. In this case Eq. (1) gives the rate of respiration but the value is negative. The respiration in the daytime was not measured, because under strong radiation the wrapping of leaves should lead to an excess elevation of leaf temperature.

On August 8 and 9, 1965, the present method was first applied to the maize plants of a height of $2.5 \mathrm{~m}$. The results are shown in Fig. 1. Around midday hours high rates of photosynthesis were recorded. If a proper dry matter/ absorbed $\mathrm{CO}_{2}$ ratio is assumed, these rates can be converted into the rate of $\mathrm{CO}_{2}$ absorption. In the present paper we tentatively used a value of 0.61 assuming that all photosynthates were accumulated in the form of starch. The calculated rates of $\mathrm{CO}_{2}$ absorption in our maize leaves attained 45 to $50 \mathrm{mg} \mathrm{CO}_{2} /$ $\mathrm{dm}^{2} / \mathrm{hr}$, very high values that are comparable to those reported recently in this species of plant. Another point of Fig. 1 is the markedly high rates of translocation in the daytime compared with the rate at night.

Table 1. The effect of duration of steaming on the rate of dry matter accumulation of maize leaves $\left(\mathrm{mg} / \mathrm{dm}^{2} / \mathrm{hr}\right)$. The number in brackets shows the number of leaves used. Steaming was applied to basal parts of the blades.

\begin{tabular}{ccc} 
Duration of steaming & $\begin{array}{c}\text { Mean rate of dry } \\
\text { matter accumulation }\end{array}$ & Standard deviation \\
\hline 2 minutes & $17.7(10)$ & 3.9 \\
$1 / 2$ minute & $16.5(4)$ & 2.7 \\
0 minute & $6.8(4)$ & 2.2 \\
(control) &
\end{tabular}


From the results given above we concluded that the present method is promising if each measurement is completed in a short period of about two hours to reduce the effect of leaf shrinkage and of suspended outflow. Longer periods used for respiratory measurement would have no adverse effect.

\section{Results}

In 1966 the diurnal changes of dry matter accumulation were pursued in sunflower and maize leaves. Sunflower plants (Helianthus annuus 'Large Russian') were grown at the experimental field of the Tokyo University of Agriculture and Technology at Koganei, Tokyo. The seeds were sown on May 14. Materials were selected from the leaves fully expanded but not shaded by the other leaves. Maize plants (Zea mays) were grown at the Experimental Farm of the Agricultural Experiment Station, $45 \mathrm{~km}$ north of Tokyo. Our measurements were made in parallel with the aerodynamic measurements conducted by another research group ${ }^{8)}$. The sample leaves were the third to fifth leaves of the border plants counted from the protruded one of the top at the southern periphery of the maize crop. They were exposed to the sun nearly all daylight hours. The mean diurnal temperature was $23-29^{\circ}$ in the experimental period and the mean night temperature was about $4^{\circ}$ lower.

The results of the sunflower leaves are illustrated in Figs. 2, 3 and 4 . The diurnal change of the rate of photosynthesis measured on June 19 (Fig. 2) appeared to have reflected the change

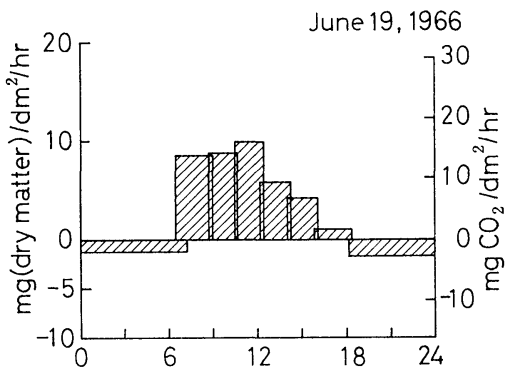

Fig. 2. Diurnal variations in the rate of photosynthesis and the mean rate of night respiration. The first sunflower experiment.
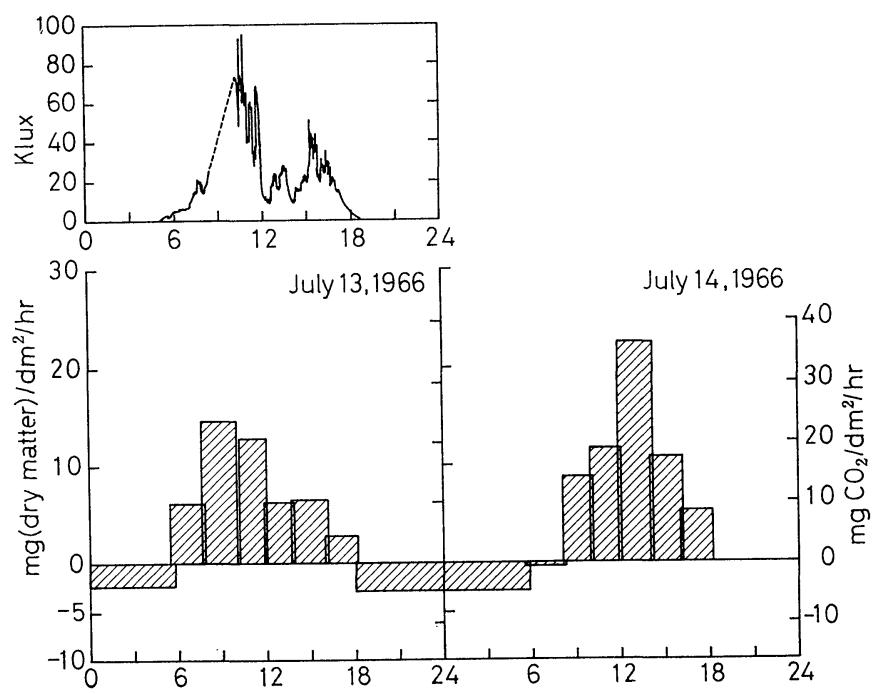

Fig. 3. Diurnal variations in the rate of photosynthesis and the mean rate of night respiration. The second sunflower experiment. 
of light intensity of this day, but the record of light intensity was incomplete and not given in the figure. The second experiment was made on two successive days of July 13 to 14 (Fig. 3), when the plants attained an average height of $95 \mathrm{~cm}$. The weather was cloudy in both days. The rate of photosynthesis was parallel to the intensity of light and not saturated with light. The maximum rate observed at midday on the second day was $23 \mathrm{mg}$ dry matter $/ \mathrm{dm}^{2} / \mathrm{hr}$, corresponding to a very high $\mathrm{CO}_{2}$ absorption rate. The respiratory losses of dry matter during nighttime were also large. In the third experiment the plants were $1.8 \mathrm{~m}$ high. Fully grown large leaves $\left(500-1000 \mathrm{~cm}^{2}\right)$ were used. The pattern of diurnal change of photosynthesis was not necessarily parallel to the change of incident light intensity: In the afternoon $\mathrm{CO}_{2}$ fixation was somewhat reduced (Fig. 4). The maximum rate obtained was the highest in this series of sunflower experiment, being nearly $28 \mathrm{mg}$ dry matter $/ \mathrm{dm}^{2} / \mathrm{hr}$ or $45.5 \mathrm{mg} \mathrm{CO} / \mathrm{Cm}^{2} / \mathrm{hr}$. The translocative outflow took place largely in the daytime, and its maximum rate was observed a little after the maximum rates of $\mathrm{CO}_{2}$ fixation were attained. Nocturnal respiration rate was again high, compared with those measured by gasometric method.

Fig. 5 gives the daily change of photosynthetic rate in maize leaves. The rate appears to be parallel with the change of incident light intensity. The maximum rate attained was $40 \mathrm{mg}$ dry matter $/ \mathrm{dm}^{2} / \mathrm{hr}$, which is comparable to the highest rate obtained recently with the gasometric leaf-chamber methods. The incident light
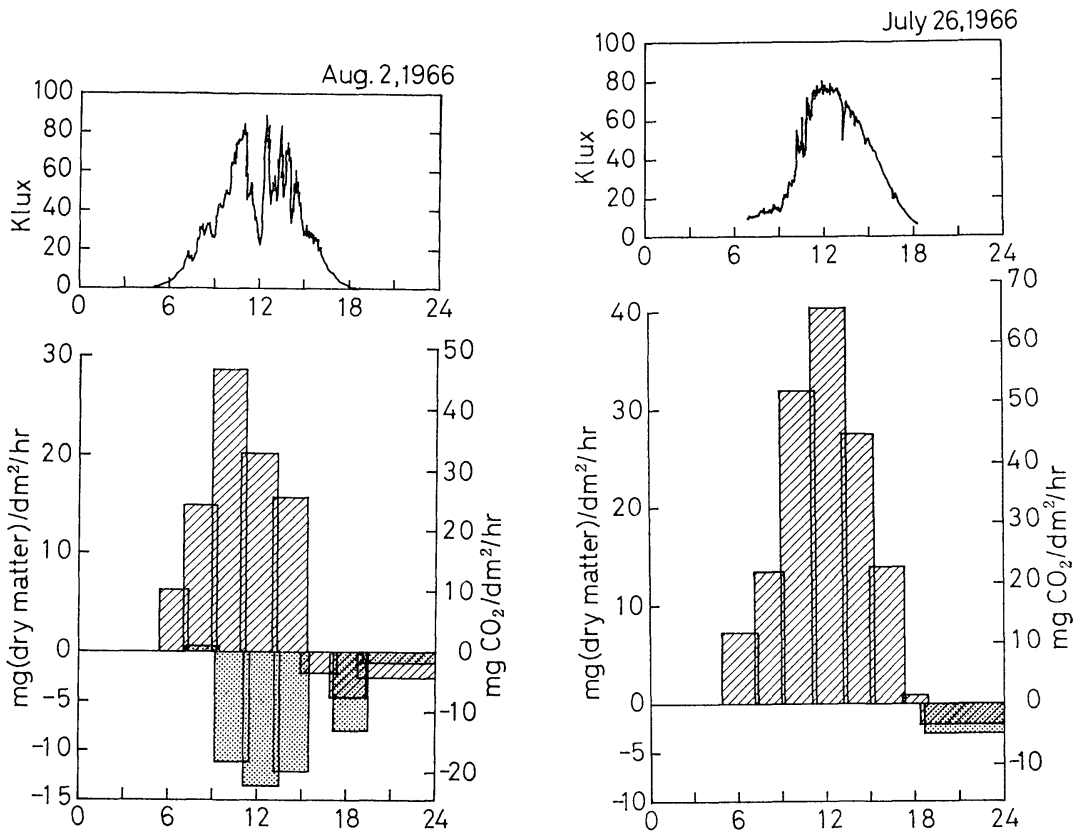

Fig. 4.

Fig. 5 .

Fig. 4. Diurnal variations in the rates of photosynthesis and translocation, together with the mean rates of night respiration and translocation. Indications are as shown in Fig. 1. The third sunflower experiment.

Fig. 5. Diurnal variations in the rate of photosynthesis, and the mean rates. of night respiration and translocation. Indications are as shown in Fig. 1. The first maize experiment. 
intensity approached to $80 \mathrm{Klux}$ at noon, but still no saturation phenomenon was observed.

The next experiment was made in the later growth stage, when the maize plants were $2.7 \mathrm{~m}$ and had already tasseled. Fig. 6 shows the rates of photosynthetic accumulation, respiratory loss and translocative outflow. The rate of photosynthesis was again striking. It is apparent that the translocation closely followed the photosynthetic performance.

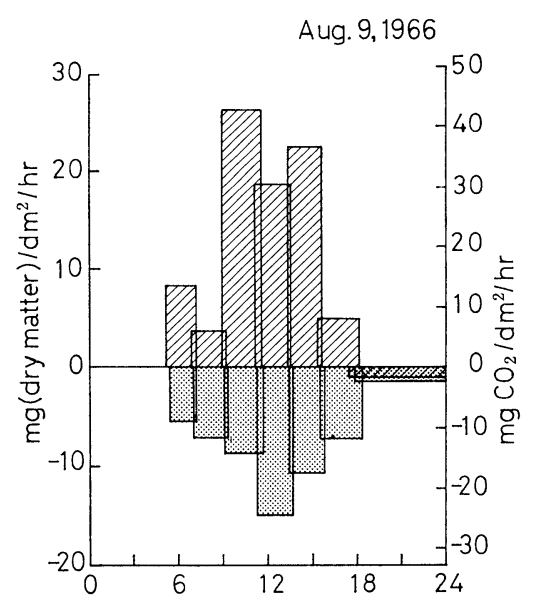

Fig. 6. Diurnal variations in the rates of photosynthesis and translocation, together with the mean rates of night respiration and translocation. Indications. are as shown in Fig. 1. The second maize experiment.

\section{Discussion}

The half-leaf method is one of the gravimetric methods for estimating the amount of photosynthetic $\mathrm{CO}_{2}$ fixation. Thoday recommended the half-leaf method as an excellent means to investigate outdoor performance of photosynthesis ${ }^{2}$. The method was, however, replaced soon by the leaf-chamber method not only in laboratory experiments but also in such field practices. There was a blind belief to the leaf-chamber method, until recently the improvements of the leaf-chamber method disclosed very high rates of $\mathrm{CO}_{2}$ fixation which are comparable to, or higher than, those obtained by the half-leaf method.

Czechoslovakian investigators established another gravimetric method, which involves the confinement of leaf disks or fragments in a wet chamber. The method completely eliminates the probable error caused by shrinkage and translocation, but appears rather proper to the laboratory studies, such as disclosing the photosynthetic responses to the experimental conditions.

Thoday's improvements of the half-leaf method $^{2)}$ still had difficulty in estimating: the rate of translocation that is proceeding simultaneously with $\mathrm{CO}_{2}$ fixation. Darkening of leaves apparently alters the real situation. In the present improvement, therefore, we utilized the steaming technique, which plant physiologists have often employed to stop the translocation stream. The detachment and darkening of leaves are not involved.

Although many reports suggested an inhibitory effect of accumulated assimilates upon the photosynthetic activity of leaves, Nátr and Špidla ${ }^{9)}$ did not find such in- 
hibition in their leaf segments or disks for 12 hours or sometimes for much longer intervals ${ }^{10)}$. Short sampling intervals adopted in the present investigation would have excluded the possibility of such inhibitory influence of accumulated assimilates.

The amount of translocation was calculated as the difference of dry matter accumulation between the control leaves and the leaves whose petioles were steamed. All the data available in this report indicate that in the two species employed the translocation closely follows the photosynthetic accumulation of matter and most part of it occurs in daylight hours.

Sachs $^{1)}$ obtained $16.5 \mathrm{mg}$ dry matter $/ \mathrm{dm}^{2} / \mathrm{hr}$ as the maximum rate of photosynthesis in sunflower leaves under natural conditions, which was later confirmed by Thoday ${ }^{32}$. The maximum values in the present investigation were $28 \mathrm{mg} / \mathrm{dm}^{2} / \mathrm{hr}$ in the third sunflower experiment and $40 \mathrm{mg} / \mathrm{dm}^{2} / \mathrm{hr}$ in the first maize experiment. At first sight these values appear too high. According to El-Sharkawy and Hesketh ${ }^{11)}$, however, the generalized photosynthetic rates obtained by the improved leaf-chamber methods were $45 \mathrm{mg} \mathrm{CO} \mathrm{CO}_{2} / \mathrm{dm}^{2} / \mathrm{hr}$ for sunflower and $60 \mathrm{mg} \mathrm{CO} / \mathrm{dm}^{2} / \mathrm{hr}$ for maize, which respectively correspond to $27-29 \mathrm{mg}$ dry matter $/ \mathrm{dm}^{2} / \mathrm{hr}$ and $37-38 \mathrm{mg} / \mathrm{dm}^{2} / \mathrm{hr}$ (assuming $1 \mathrm{~g} \mathrm{CO}=0.61-0.64 \mathrm{~g}$ dry matter). Warren Wilson ${ }^{12)}$ reported a net assimilation rate of $2.0 \mathrm{~g} / \mathrm{dm}^{2} /$ week in sunflower plants, which was suggested to correspond to a photosynthetic rate of $32-42 \mathrm{mg}$ dry matter $/ \mathrm{dm}^{2} / \mathrm{hr}$ in the most active leaves. After surveying all these data we see our high values are not exceptional at all.
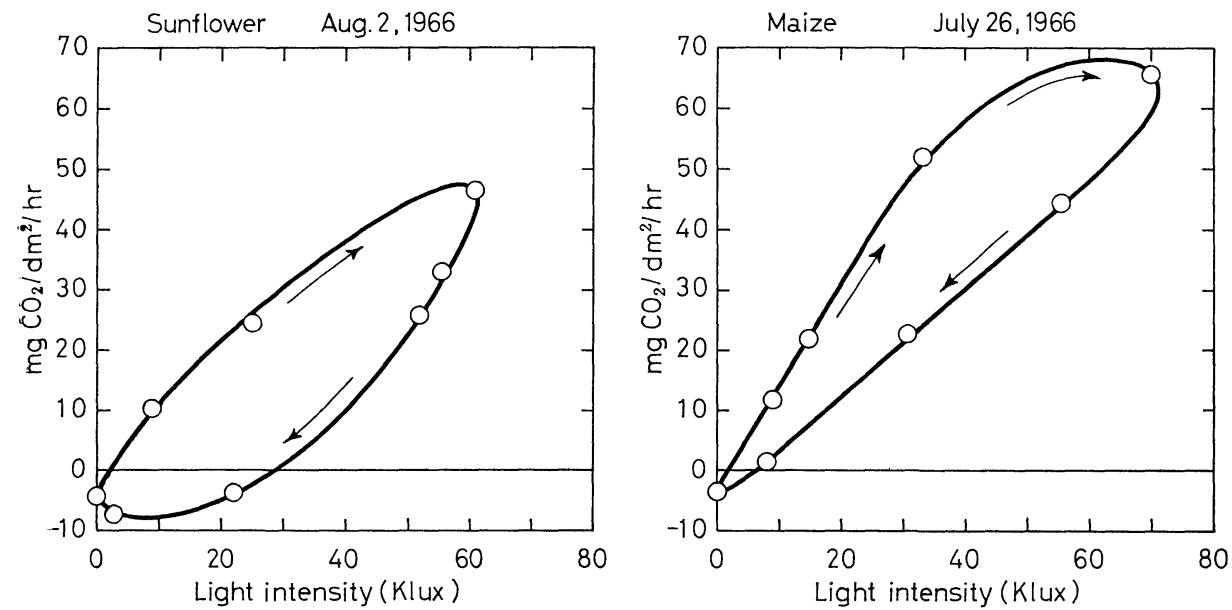

Fig. 7. Photosynthetic rates as related to solar light intensity. Led from the data in Fig. 4 (left) and from the data in Fig. 5 (right).

Fig. 7 illustrates the photosynthetic rates plotted against light intensities in the third sunflower experiment and the first maize experiment. We recognize that the morning values are higher than the afternoon values. The depression in the afternoon might have been caused by some reduction in stomatal opening and/or leaf shrinkage by a small deficit of water content of leaves, though there was no sign of flaccidity of leaves.

The present half-leaf method could be employed for obtaining the vertical gradients of photosynthetic rate within the foliage. The results will be reported in the next paper. 


\section{References}

1) Sachs, J., Arb. a. d. Bot. Inst. Würzburg $3: 19$ (1883).

2) Thoday, D., Proc. Royal Soc. London, Ser. B $82: 1$ (1910).

3) - ibid. $82: 421$ (1910).

4) Mudrack, F., Planta 23: 71 (1935).

5) Tranquillini, W., Ber. d. dtsch. Bot. Ges. 67 : 191 (1954).

6) Bosian, G., Planta $45: 470$ (1955).

7) Gaastra, P., Meded. Landbouwhogeschool, Wageningen 59: 1 (1959).
8) Uchijima, Z., Udagawa, T., Horie, T. and Kobayashi, K., J. Agric. Meteorl. (Jap.) 23 : 99 (1967).

9) Nátr, L., and Špidla, Biol. Plant. 3: 245 (1961).

10) Nátr, L., Photosynthetica 1: 29 (1967).

11) El-Sharkawy, M. and Hesketh, J., Crop Sci. 5 : 517 (1965).

12) Warren Wilson, J., Ann. Bot. N.S. 30 : 745 (1966).

\section{摘}

要

野本宣夫* ・佐伯敏郎**：改良半葉法により測られたヒマワリと トウモロコシの葉の乾量增加

自然条件下の測定にさいして，Sachs の半葉法の利点を生かすために次の改良を行なった。葉からの転

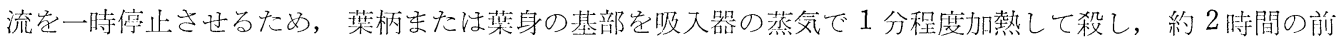
後に扮ける左右両半葉試料の単位面積あたりの乾量の差を（1）式に往って求め，光合成による乾量增加速 度とした。蒸父処理で葉柄が折れやすくなった場合にはアルミはくで補強した。夜間の呼吸量の測定も同 じ操作により，アルミはくで葉をゆるく抒っって，夕方と明けがたの光をさえぎり，その間の乾量減少量 を同じ (1) 式によって求めた。転流速度は, 蒸気処理をした葉としない葉の平坋乾量増加量の差として求 めた.

この方法はヒマワリおよびトウモロコシの，よく日のあたった若い成熟茶に対して試みられ，ヒマワリ で 3 回（第 $2 ， 3 ， 4$ 図），トウモロコシで 2 回（第 $3 ， 4$ 図）の光合成速度，夜間呼吸量，転流速度の日变化 が求められた。得られた光合成による乾量増加速度は，ほぼ光の強さの日变化と平行に進み，その最大值 は正午頃ヒマワリで $28 \mathrm{mg} / \mathrm{dm}^{2} / \mathrm{hr}$, トウモロコシで $40 \mathrm{mg} / \mathrm{dm}^{2} / \mathrm{hr}$ となった. $\mathrm{CO}_{2} 1 \mathrm{mg}$ が乾量 $0.61 \mathrm{mg}$ に相当すると仮定すると，上の值はとれぞれ約 $46 \mathrm{mg} \mathrm{CO}_{2} / \mathrm{dm}^{2} / \mathrm{hr}$ と $65 \mathrm{mg} \mathrm{CO} \mathrm{CO}_{2} / \mathrm{dm}^{2} / \mathrm{hr}$ とになり，非 常に高い值であった。これらはしかし最近同化箱法の改良でガス分析計によって得られるようになった值 と同じレベルにある。また転流は光合成による乾量增加に少し出くれて変化したが，ほぼ似た形の变化で あったので，この両種では転流の大部分が㡺間起ったことが示された.

(* 荻城大学理学部生物学教室. ** 東京大学理学部植物学教室) 